Journal of Materials and

Environmental Sciences

ISSN : 2028-2508

CODEN : JMESCN

\title{
Seasonal variations in the phenolic compound content and antioxidant activities of three selected species of seaweeds from Tiskerth islet, Bejaia, Algeria
}

\author{
F. Fellah", H. Louaileche, A. Dehbi-Zebboudj, N. Touati \\ Laboratoire de Biochimie Appliquée, Faculté des Sciences de la Nature et de la Vie, Université de Bejaia, 06000 Bejaia, \\ Algeria
}

\author{
Received 11 Dec 2016, \\ Revised 17 Jan 2017 , \\ Accepted 20 Jan 2017 \\ Keywords \\ $\checkmark$ Phenolic compound; \\ $\checkmark$ Antioxidant activities; \\ $\checkmark$ Seaweeds; \\ $\checkmark$ Seasonal variation; \\ FFellah \\ fahimafellah@gmail.com \\ $\mathbf{+ 2 1 3 5 5 1 6 3 7 2 8 3}$
}

\begin{abstract}
The seasonal variations in the total phenolic contents and potential antioxidant activities of three seaweed species (Halopteris scoparia, Zonaria tournefortii, Sphaerococcus coronopifolius) were assessed. The highest total phenolic content was recorded during autumn in the seaweeds $S$. coronopifolius $(144.33 \pm 1.76 \mathrm{mg}$ GAE/100g) and $H$. scoparia $(105.40 \pm 1.19 \mathrm{mg} \mathrm{GAE} / 100 \mathrm{~g})$. The highest ascorbic acid content was observed in $H$. scoparia $(125.52 \pm 2.79 \mathrm{mg} \mathrm{AAE} / 100 \mathrm{~g})$ in spring. The total antioxidant activity $(699.13 \pm 2.23 \mathrm{mg}$ GAE $/ 100 \mathrm{~g})$ and the ferric reducing power $(54.69 \pm 0.75 \mathrm{mg} \mathrm{GAE} / 100 \mathrm{~g})$ were found to be high in $S$. coronopifolius during spring and autumn respectively, whereas the ferrous iron chelation in $H$. scoparia during the three seasons (varied from $321.66 \pm 8.82$ to $340.05 \pm 1.81 \mathrm{mg}$ GAE $/ 100 \mathrm{~g})$. The DPPH radical scavenging activity $(12.08 \pm$ $0.28 \mathrm{mg} \mathrm{GAE} / 100 \mathrm{~g}$ ) was found to be high in Z. tournefortii during summer.
\end{abstract}

\section{Introduction}

Algae, as photosynthetic organisms, are exposed to a combination of light and high oxygen concentration at the origin of the formation of free radicals and other oxidative reagents [1]. But the awareness of the lack of structural damage in their organs has led the scientific community to consider that their resistance to oxidation comes from their natural content, or production under stress, in antioxidant substances [1]. Many studies indicate that extreme environmental factors, e.g. salinity, temperature, nutrients, and intense irradiance, cause a high rate of pigment production [2-5]. The biochemical composition of marine algae is generally known to be highly influenced by geographical location, environment, season and sampling conditions $[6,7]$. The biomass of algae contains many valuable components: minerals, vitamins (A, B, C, E), PUFAs ( $\omega-3)$, amino acids, proteins, polysaccharides, lipids, and dietary fiber [8]. Some of these substances were studied for their biological properties [8-17]. Furthermore, Seasonal variations in the chemical composition and biological activity have been reported in common marine seaweeds from different parts of the world [18-23].

However, there is paucity of data on the antioxidant potential of seaweeds harvested in Algeria. Reports on the biological activities of seaweed extracts from Algeria are very limited [24-26]. In addition, any studies evaluating the seasonal variation in the chemical composition of these Algerian seaweeds were accomplished. Hence, the present study was intended to investigate the seasonal variations in the phenolic compound content and antioxidant activities of algal extracts from the Algerian Sea. The study focused on species that are among the most abundant in our study area, and that could become a natural source for the extraction of metabolites with antioxidant properties for use in pharmaceutical and medical sectors.

\section{Experimental details}

\subsection{Seaweed material}

Three marine algal species were collected during December 2013, June and September 2014, representing Autumn, Spring and Summer respectively in Tiskerth (Ile de l'ail) which is a small islet in the Boulimat region about $16.4 \mathrm{~km}$ west of Bejaia city. The species collected were the pheophytes Halopteris scoparia (Linnaeus) Sauvageau, Zonaria tournefortii (Lamouroux) Montagne, and the rhodophyte Sphaerococcus coronopifolius Stackhouse. The algae were collected from submerged rocks from 6-7 m depth where they are usually abundant 
during the relevant collecting periods. All the samples were brought to the laboratory in plastic bags containing seawater to prevent the seaweeds from drying out. Samples has been cleaned several times in fresh water and then with distilled water. After cleaning, the algae was shade- drying at room temperature for one week then oven dried at $38 \pm 2^{\circ} \mathrm{C}$ for $48 \mathrm{~h}$ to obtain a constant weight and pulverized in the grinder and sieved through a screen with an aperture of $125 \mu \mathrm{m}$. Then, the powdered material was kept in airtight glass bottles at room temperature until further analysis.

\subsection{Chemicals}

2-2-diphenyl-1-picrylhydrazyl (DPPH), 2,6-dichlorophenolindophenol (DCPIP) were purchased from SigmaAldrich Chemie (Steinheim, Germany). Sodium carbonate, potassium ferricyanide (P 99.5\% purity) was purchased from Biochem, Chemopharma (USA), while Ferric chloride (P 98.102\% purity) was from Panreac (Barcelona, Spain). Folin-Ciocalteu reagent, acid sulfuric, hexane, acetone and trichloroacetic acid ( $\geq 99.00 \%$ purity) were obtained from Biochem, Chemopharma (Montreal, Quebec). All other solvents and chemicals were of analytical grade.

\subsection{Preparation of extracts}

The pulverized seaweed material $(0.5 \mathrm{~g})$ was weighed and $50 \mathrm{ml}$ of distilled water added to it. The water extract solution was collected after shaking for $1 \mathrm{~h}$ at room temperature and centrifugation at $2220 \mathrm{rpm}$ during $10 \mathrm{~min}$.

\subsection{Total phenolic content (TPC)}

The total phenolic content in the extracts was determined by the method described by Singleton \& Rossi [27] slightly modified. An aliquot $(100 \mu \mathrm{l})$ of extract was mixed with $0.5 \mathrm{ml}$ of Folin-Ciocalteu reagent (1:10 diluted) and allowed to stand at room temperature for $5 \mathrm{~min}$. Sodium carbonate $(7.5 \%, 0.4 \mathrm{ml})$ was added to the mixture and incubated at room temperature for $2 \mathrm{~h}$. The absorbance was measured at $760 \mathrm{~nm}$. The content of phenolic compounds was expressed as mg gallic acid equivalent (GAE) per 100g dry weight of sample (DW).

\subsection{Ascorbic acid content (AAC)}

Ascorbic acid was determined according to the method of Mau et al. [28]. Two hundred milligrams of each sample were extracted with $10 \mathrm{~mL}$ of oxalic acid (3\%) for $60 \mathrm{~min}$. After centrifugation at $1700 \times \mathrm{g}$ for $15 \mathrm{~min}$, the supernatant was paper filtered. One milliliter of extract was mixed with $9 \mathrm{~mL}$ of DCPIP and the absorbance was measured at $515 \mathrm{~nm}$. Ascorbic acid content was expressed as mg ascorbic acid equivalents (AAE) per 100g dry weight of sample (DW).

\subsection{Antioxidant activities}

\subsubsection{Total antioxidant capacity (TAC)}

Total antioxidant activities were determined according to the method of Prieto et al. [29]. Briefly, $0.2 \mathrm{ml}$ of sample was mixed with $2.0 \mathrm{ml}$ reagent solution $(0.6 \mathrm{M}$ sulfuric acid, $28 \mathrm{mM}$ sodium phosphate and $4 \mathrm{mM}$ ammonium molybdate). Reaction mixture was incubated at $95{ }^{\circ} \mathrm{C}$ for 90 min under water bath. Absorbance of all the sample mixtures was measured at $695 \mathrm{~nm}$. Total antioxidant activity was expressed as $\mathrm{mg}$ gallic acid equivalent (GAE) per 100g dry weight of sample (DW).

\subsubsection{Ferric reducing power (FRP)}

The reducing power was measured according to the method of Oyaizu [30]. To $1 \mathrm{ml}$ of extract was added $1 \mathrm{ml}$ $0.2 \mathrm{M}$ phosphate buffer ( $\mathrm{pH}$ 6.6) and $1 \mathrm{ml}$ of $1 \%$ potassium ferricyanide. The mixture was incubated at $50{ }^{\circ} \mathrm{C}$ for $20 \mathrm{~min}$ and $1 \mathrm{ml}$ of $10 \%$ TCA was added into this reaction mixture. An aliquot of $1 \mathrm{ml}$ from the incubation mixture was mixed with $1 \mathrm{ml}$ of distilled water and $0.2 \mathrm{ml}$ of $0.1 \%$ ferric chloride in test tubes. The absorbance was measured at $700 \mathrm{~nm}$. Gallic acid was used as a standard and reducing power was expressed as mg gallic acid equivalents (GAE) per 100g dry weight of sample (DW).

\subsubsection{DPPH radical scavenging activity}

DPPH radical scavenging activity was determined according to the method of Blois [31]with slight modification. Briefly, $1 \mathrm{ml}$ of $60 \mu \mathrm{M}$ methanolic solution of DPPH was mixed with $500 \mu \mathrm{l}$ of extract solution. The mixture was then shaken and left for $30 \mathrm{~min}$ at room temperature in the dark. The absorbance of the resulting solution was measured at $517 \mathrm{~nm}$. Gallic acid was used as a standard and DPPH radical scavenging activity was expressed as mg gallic acid equivalents (GAE) per 100g dry weight of sample (DW). 


\subsubsection{Ferrous iron chelation (FIC)}

The $\mathrm{Fe}^{2+}$ chelating activity of the extracts was estimated by the modified method of Dinis et al.[32]. To $1 \mathrm{ml}$ of the extract $2.7 \mathrm{ml}$ of deionised water and $0.1 \mathrm{ml}$ of $2 \mathrm{mM}$ ferrous chloride were added. After $3 \mathrm{~min}, 5 \mathrm{mM}$ ferrozine $(0.2 \mathrm{ml})$ were added. The mixture was shaken vigorously and was left at room temperature for $10 \mathrm{~min}$. The absorbance of the resulting solution was measured at 562. A control was run in the same way using distilled water instead of sample. Sample blank was made for each extract without adding ferrozine. The chelating capacity expressed as mg gallic acid equivalents (GAE) per 100g dry weight of sample (DW).

\subsection{Statistical analysis}

All analyses were carried-out in triplicates and the experimental data were expressed as means \pm standard deviation using Graphpad prism 7. Analysis of variance was determined by two-way ANOVA. The Tukey test was performed and the significant difference was detected at $\mathrm{p}<0.05$.

\section{Results}

\subsection{Total phenolic content}

Based on the absorbance values of extract reacted with the Folin-Ciocalteu reagent, total phenolic contents are given in Figure 1, as gallic acid equivalents by reference to standard curve.TPC was higher in S. coronopifolius $(144.33 \pm 1.76 \mathrm{mg}$ GAE$/ 100 \mathrm{~g})$ in autumn followed by $H$. scoparia $(105.40 \pm 1.19 \mathrm{mg}$ GAE/100g)in the same season and Z. tournefortii $(78.46 \pm 0.79 \mathrm{mg} \mathrm{GAE} / 100 \mathrm{~g})$ in summer. TPC was observed to vary in all seasons. Tukey tests showed the significant seasonal differences $(\mathrm{p}<0.05)$ between the different species as well as within each species.

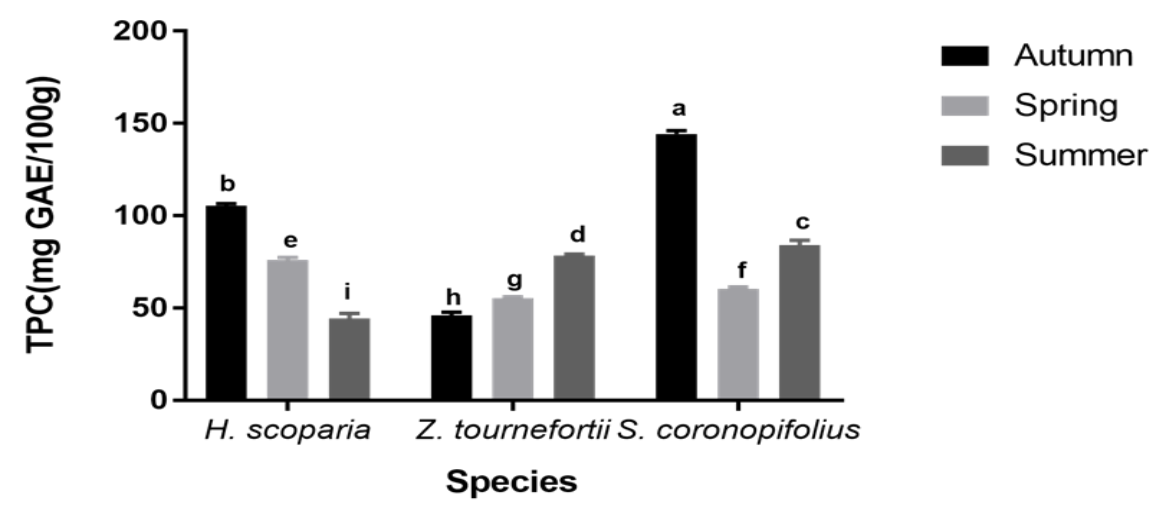

Figure 1: Total phenolic contents of three selected marine algae in three seasons.

\subsection{Ascorbic acid content}

As can be seen in Figure 2, the highest ascorbic acid content was observed in $H$. scoparia (125.52 $\pm 2.79 \mathrm{mg}$ $\mathrm{AAE} / 100 \mathrm{~g})$ in spring and in Z. tournefortii $(109.01 \pm 4.18 \mathrm{mg} \mathrm{AAE} / 100 \mathrm{~g})$ in Autumn whereas the lowest ascorbic acid level occurring in all seasons found in the seaweed $S$. coronopifolius.

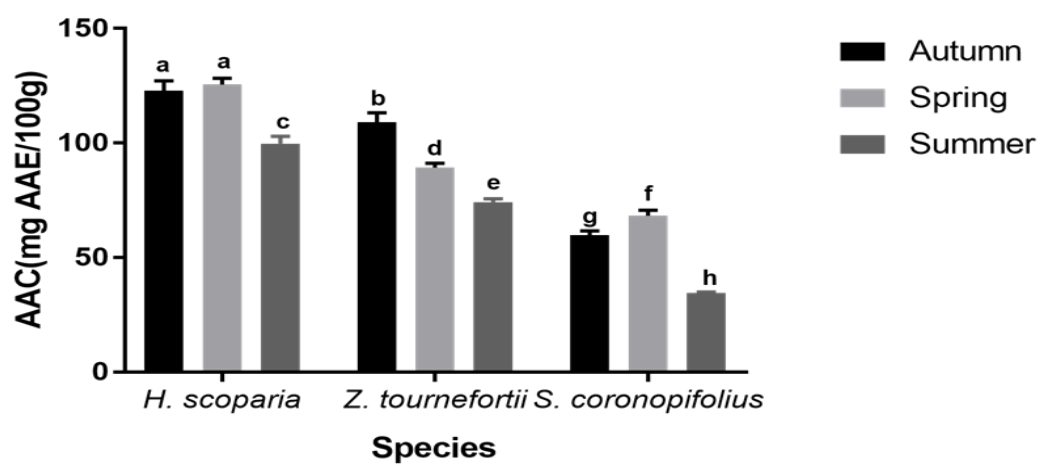

Figure 2: Ascorbic acid contents of three selected marine algae in three seasons

The seasonal differences in ascorbic acid content were significant $(\mathrm{p}<0.05)$ in two of the three algal species $(Z$. tournefortii and $S$. coronopifolius), the exception being $H$. scoparia which showed an insignificant difference $(\mathrm{p}<0.05)$ between its autumn and spring contents $(\mathrm{AAC})$ 


\subsection{Antioxidant activities}

The antioxidant activities of the macroalgal species varied both between species and with time (Table I).

Table I: The antioxidant activities of three algal species collected at Bejaia Bay in different seasons. The values are expressed as mean $\pm \mathrm{SD}(\mathrm{n}=3)$.

\begin{tabular}{|c|c|c|c|c|c|}
\hline Species & Seasons & $\begin{array}{c}\text { TAC } \\
\text { (mgGAE/100g) }\end{array}$ & $\begin{array}{c}\text { FRP } \\
\text { (mgGAE/100g) }\end{array}$ & $\begin{array}{c}\text { DPPH } \\
\text { (mgGAE/100g) }\end{array}$ & $\begin{array}{c}\text { FIC } \\
\text { (mgGAE/100g) }\end{array}$ \\
\hline H. scoparia & Autumn & $322.36 \pm 5.12 \mathrm{~d}$ & $40.77 \pm 1.80 \mathrm{a}$ & $11.12 \pm 0.19 \mathrm{~b}$ & $321.66 \pm 8.82 \mathrm{~b}$ \\
& Spring & $277.66 \pm 5.76 \mathrm{f}$ & $41.93 \pm 1.08 \mathrm{a}$ & $7.77 \pm 0.13 \mathrm{c}$ & $340.05 \pm 1.81 \mathrm{a}$ \\
& Summer & $218.55 \pm 2.57 \mathrm{~h}$ & $20.87 \pm 0.35 \mathrm{f}$ & $5.32 \pm 0.87 \mathrm{~g}$ & $333.24 \pm 4.77 \mathrm{a}$ \\
\hline Z. tournefortii & Autumn & $246.41 \pm 3.35 \mathrm{~g}$ & $31.02 \pm 1.45 \mathrm{c}$ & $3.73 \pm 0.28 \mathrm{~h}$ & $174.93 \pm 3.96 \mathrm{e}$ \\
& Spring & $242.94 \pm 4.43 \mathrm{~g}$ & $26.07 \pm 0.35 \mathrm{e}$ & $6.61 \pm 0.14 \mathrm{e}$ & $163.17 \pm 1.96 \mathrm{f}$ \\
& Summer & $278.97 \pm 5.16 \mathrm{e}$ & $23.94 \pm 1.65 \mathrm{e}$ & $12.08 \pm 0.28 \mathrm{a}$ & $81.69 \pm 0.83 \mathrm{~h}$ \\
& & & & & \\
\hline S. coronopifolius & Autumn & $636.57 \pm 7.63 \mathrm{~b}$ & $54.69 \pm 0.75 \mathrm{~b}$ & $5.76 \pm 0.04 \mathrm{f}$ & $276.02 \pm 1.79 \mathrm{c}$ \\
& Spring & $699.13 \pm 2.23 \mathrm{a}$ & $18.62 \pm 0.55 \mathrm{~g}$ & $3.69 \pm 0.05 \mathrm{i}$ & $176.69 \pm 2.80 \mathrm{~d}$ \\
& Summer & $516.3 \pm 8.28 \mathrm{c}$ & $27.00 \pm 0.91 \mathrm{~d}$ & $7.24 \pm 0.18 \mathrm{~d}$ & $141.61 \pm 5.21 \mathrm{~g}$ \\
& & & & & \\
\hline
\end{tabular}

Values with the same letter in each separate parameter are insignificant (two-way ANOVA, p<0.05)

\subsubsection{Total antioxidant capacity}

The total antioxidant activity of three different seaweeds are presented in Table I. S. coronopifoliusshowed highest total antioxidant activity $(699.13 \pm 2.23 \mathrm{mg}$ GAE$/ 100 \mathrm{~g})$ followed by $H$. scoparia $(322.36 \pm 5.12 \mathrm{mg}$ GAE/100 g) and Z.tournefortii (278.97 $\pm 5.16 \mathrm{mg}$ GAE/100g). Significant seasonal differences (two-way ANOVA, p $<0.05$ ) were observed in the total antioxidant capacity in $H$. scoparia and $S$. coronopifolius, but insignificant differences in Z.tournefortii (Autumn vs. Spring).

\subsubsection{Ferric reducing power}

The ferric reducing power was observed to be higher in autumn with the highest level being recorded in $S$. coronopifolius $(54.69 \pm 0.75 \mathrm{mg} \mathrm{GAE} / 100 \mathrm{~g})$ followed by $H$. scoparia $(40.77 \pm 1.80 \mathrm{mg} \mathrm{GAE} / 100 \mathrm{~g})$ than $Z$. tournefortii $(31.02 \pm 1.45 \mathrm{mg} \mathrm{GAE} / 100 \mathrm{~g})$. The Tukey test revealed that all the seaweed species had significant difference in the antioxidant activities (FRP assay) in all seasons with the exception of $H$. scoparia and $Z$. tournefortii where by its antioxidant activities wereinsignificantly different $(\mathrm{p}<0.05)$ in Autumn vs.Spring and Spring vs. Summer respectively. On the other hand, the differences between the ferric reducing power during summerin $H$. scoparia vs. Z. tournefortii and Z. tournefortii vs. S. coronopifolius were insignificant.

\subsubsection{DPPH radical scavenging activity}

The free radical scavenging activity in the three seaweed species were relatively low (Table 1). The maximum activity was found in $Z$. tournefortii $(12.08 \pm 0.28 \mathrm{mg}$ GAE$/ 100 \mathrm{~g})$ in summer and $H$. scoparia $(11.12 \pm 0.19 \mathrm{mg}$ $\mathrm{GAE} / 100 \mathrm{~g}$ ) in autumn. The free radical scavenging activity showed significant seasonal differences (two-way ANOVA, $\mathrm{p}<0.05$ ) between the different species as well as within each species.

\subsubsection{Ferrous iron chelation (FIC)}

As shown in Table I, H. scopariaattained the highest ferrous chelating activity (FIC) during the three seasons (varied from $321.66 \pm 8.82$ to $340.05 \pm 1.81 \mathrm{mg} \mathrm{GAE} / 100 \mathrm{~g}$ ). Tukey tests showed that the FIC was significantly different between seasons in all species with the exception of $H$. scoparia which showed an insignificant difference $(\mathrm{p}<0.05)$ between its spring and summer activity.

\section{Discussion}

Our results demonstrate that the total phenolic content was significantly higher in autumn in both species $S$. coronopifolius and $H$. scopariaas opposed to $Z$. tournefortii, which showed the highest phenolic content in summer. Similar observations have been reported previously, with maxima observed from late summer to the middle winter [33]. However, other studies have described maximum levels in summer [5, 19, 20, 34] depending on the species.On the other hand, Phaeophyta results reported to contain comparatively higher contents and more active antioxidants than green and red algae $[35,36]$. However, in our study, the rhodophyte $S$. coronopifolius showed highest total phenolic content comparing with the brown algae H. scoparia andZ. tournefortii. It could be that the annual variation in phenolic content are dependent on a diverse species 
composition, as well as on the different environmental conditions obtaining in each season. The phenolic compound content of macroalgae varies with the reproductive stage of algae [19, 37] and with the physical factors such as light density and quality, photoperiod and temperature [4]. In order to survive under the worst conditions, algae contain some unique components not discovered in plants and these components differ according to algal species [38]. Gobbo-Neto \& Lopes [39] report that these factors have correlations with each other and do not act in isolation; they may jointly influence the secondary metabolism.

In addition, we found that the three marine algae contained phenolic constituents in various proportions and showed antioxidant activity to various degrees. A high correlation between the total phenolic content and antioxidant activity has been reported by many researchers [10, 19, 40, 41]. Nevertheless, other reports indicated that this correlation doesn't exist and it was concluded that phenolic compounds are not responsible for antioxidant activity [42, 43]. In our study the red alga, S. coronopifolius exhibited higher total antioxidant capacity and ferric reducing power than $H$. scopariaandZ. tournefortii because of its richness of total phenolic content. It was observed that the extracts containing high levels of total phenolics were also potent in reducing ferric iron, suggesting that algal polyphenols may be the principle constituents responsible for these properties of the extracts [13]. Furthermore, many researchers have been reported positive correlation between free radical scavenging activity and total phenolic compound [44-46].This is in disagreement with our results that prove weak free radical scavenging activity in all studied species. Some studies showed also a low activity in water extracts [47-48]. However, water extracts generally had higher ferrous chelating activity than $70 \%$ acetone extracts and no correlation was found with this TPC, suggesting other components such as polysaccharides, proteins or peptides in the extracts [49]. Our result is in accordance with this study, which also reported a high $\mathrm{Fe} 2+$ chelating activity of water extracts, specially with the brown algae $H$. scoparia wich attained the highest activity (FIC) during the three seasons comparing with $S$. coronopifolius wich had the highest total phenolic content. According to Toth \& Pavia [50], the phlorotanins which are usually present in brown seaweeds are strong chelators of heavy metals, which are believed to be responsible for the chelating ability of $P$. antillarum. $K$. alvarezzi. However, due to the complexity of crude algal extracts, a simple correlation between the phenolic content and the antioxidant properties is not informative. A detailed characterization of both the active components and other substances are needed [51].

\section{Conclusion}

The present study revealed pronounced seasonal variations in the phenolic compounds and the antioxydant activities of three algal species (Halopteris scoparia, Zonariatournefortii, Sphaerococcus coronopifolius). Relatively important phenol levels linked to potent antioxidant activities were observed during autumn for both species $S$. coronopifolius and $H$. scoparia. It also illustrates that the phenolic compounds and the antioxydant activities varies intra-species as well as inter-species like a function of community or season, which points to the role of biotic and abiotic factors in the production of phenolic compoundsby seaweeds.S. coronopifoliusdemonstrated distinctly higher levels of total phenolic contents, total antioxydant activity and ferric reducing power than the othertwo algal species, but ferrous chelating activity was comparatively high in $H$. scopariaduring the three seasons compared to the other species. The data generated, though preliminary, therefore contributes to the development of the data base on Algerian marine algae presenting potential pharmaceutical and medical applications.

Acknowledgments- The authors would like to thank Mr. Hafid Boudehouche and his Diving Club members for their help in the collection and sample preparation.

\section{References}

1. Zubia M., Fabre, M.S., Kerjean, V., Le Lann, K., Stiger-Pouvreau, V., Fauchon, M., \& Deslandes, E., Food Chem. 116 (2009) 693.

2. Marin N., Morales, F., Lodeiros, C., \& Tamigneaux, E., J. Appl. Phycol. 10 (1998) 405.

3. Boussiba S., Bing, W., Yuan, J.P., Zarka, A., \& Chen, F., Biotechnol. Lett. 21 (1999) 601.

4. Zucchi M.R., \& Necchi, O., Phycol. Res. 49 (2001) 103.

5. Abdala-Díaz, R.T., Cabello-Pasini, A., Pérez-Rodríguez, E. Conde Álvarez, R. M. \& Figueroa, F. L., Mar. Biol. 148 (2006) 459.

6. Renaud S. M., \& Luong-Van, J. T., J. Appl. Phycol. 18 (2006) 381.

7. Mohamed S., Hashim, S.N., \& Rahman, H.A., Trends Food Sci. Tech. 23 (2012) 83.

8. Duan X.J., Zhang, W.W., Li, X.M., \& Wang, B.G., Food Chem. 95 (2006) 37.

9. Kuda T., Kunii, T., Goto, H., Suzuki, T., \& Yano, T., Food Chem. 103 (2007) 900. 
10. Chew Y.L., Lim, Y.Y., Omar, M., \& Khoo, K.S., LWT - Food Sci. Tech. 41 (2008) 1067.

11. Bouhlal R., Haslin C., Chermann J.C., Colliec-Jouault S., Sinquin C., Simon G., Cerantola S., Riadi H., Bourgougnon N., Mar. Drugs 9 (2011) 1187.

12. Sanaa M.M. Shanab, Soha S.M. Mostafa, Emad A. Shalaby, \& Ghada I. Mahmoud, Asian Pac. J. Trop. Biomed. 2 (2012) 608.

13. Farvin K.H., \& Jacobsen, C., Food Chem. 138 (2013) 1670.

14. Lee J.C., Hou, M.F., Huang, H.W., Chang, F.R., Yeh, C.C., Tang, J.Y., \& Chang, H.W., Cancer Cell Int. 13 (2013) 55.

15. Fernando I.P., Kim, M., Son, K.T., Jeong, Y., \& Jeon, Y.J., J. Med. Food 19 (2016) 615.

16. Belattmania Z., Engelen, A.H., Pereira, H., Serrão, E.A., Barakate, M., Elatouani, S., Zrid, R., Bentiss, F., Chahboun N., Reani, A., Sabour, B., J. Mater. Environ. Sci. 7 (2016) 2074.

17. Pinteus S., Silva, J., Alves, C., Horta, A., Fino, N., Inês Rodrigues, A., Mendes, S., Pedrosa, R., Food Chem. 218 (2017) 591.

18. Kaehler S., \& Kennish, R., Bot. Mar. 39 (1996) 11.

19. Connan S., Goulard, F., Stiger, V., Deslandes, E. \& Ar Gall, E., Bot. Mar. 47 (2004) 410.

20. Parys S., Kehraus S., Pete R., Küpper F.C., Glombitza K.W., König G.M., Eur. J. Phycol. 44 (2009) 331.

21. Choi J.K., Ha, Y.M., Lee, B.B., Moon, H.E., Cho, K.K., \& Choi, I.S., J. Environ. Biol. 35 (2014) 341.

22. Veide Vilg, J., Nylund, G.M., Werner, T., Qvirist, L., Mayers, J.J., Pavia, H., Undeland, I. \& Albers, E., Bot. Mar. 58 (2015) 435.

23. Liu H., Liu, X., Jiang, A., I.J.M.S. 46 (2017) 1091.

24. Saidani K., Bedjou, F., Benabdesselam, F., \& Touati, N., Afr. J. Biotechnol. 11 (2012) 9496.

25. Guendouze-Bouchefa, N., Madani, K., Chibane, M., Boulekbache-Makhlouf, L., Hauchard, D., Kiendrebeogo, M., Stevigny, C., Okusa, P.N., \& Duez, P., Ind. Crop. Prod. 70 (2015) 459.

26. Metidji H., Dob T., Toumi M., Krimat S., Ksouri A., Nouasri A., J. Mater. Environ. Sci. 6 (2015) 3184.

27. Singleton V.L., \& Rossi, J.A., Am. J. Enol. Viticult. 16 (1965) 144.

28. Mau J.L., Tsai, S.Y., Tseng, Y.H., \& Huang, S.J., Food Chem. 93 (2005) 641.

29. Prieto P., Pineda, M., \& Aguilar, M., Anal. Biochem. 269 (1999) 337.

30. Oyaizu M., Jpn. J. Nutr. 44 (1986) 307.

31. Blois M. S., Nature 26 (1958) 1199.

32. Dinis T.C., Madeira, V.M., Almeida, L.M., Arch. Biochem. Biophys. 315 (1994) 161.

33. Ragan M.A. \& Glombitza, K.W., Prog. Phycol. Res. 4 (1986) 129.

34. Schiener P., Black, K., Stanley, M., \& Green, D., J. Appl. Phycol. 27 (2015) 363.

35. Cox S., Abu-Ghannam, N., \& Gupta, S., Int. Food Res. J. 17 (2010) 205.

36. Kindleysides S., Quek, S. Y., \& Miller, M. R., Food Chem. 133 (2012) 1624.

37. Ragan M.A., \& Jensen, A., J. Exp. Mar. Biol. Ecol. 34 (1978) 245.

38. Amer H., Emons, H., \& Ostapczuk, P., Chemosphere 34 (1997) 2123.

39. Gobbo-Neto L., Lopes, N.P., Quím. Nova 30 (2007) 374.

40. Wangensteen H., Samuelsen, A. B., \& Malterud, K. E., Food Chem. 88 (2004) 293.

41. Wang T., Jónsdóttir, R., \& Ólafsdóttir, G., Food Chem. 116 (2009) 240.

42. Kähkönen M. P., Hopia, A. I., Vuorela, H. J., Rauha, J.-P., Pihlaja, K., Kujala, T. S., \&Heinonen, M., J. Agr. Food Chem. 47 (1999) 3954.

43. Rapisarda P., Lo Bianco, M., Pannuzzo, P., \& Timpanaro, N., Postharvest Biol. Tec. 49 (2008) 348.

44. Lu Y., Foo, Y.L., J. Life Sci. 66 (2000) 725.

45. Oki T., Masuda, M., Furuta, S., Nishibia, Y., Terahara, N. \& Suda, I., Food Chem. Toxicol. 67 (2002) 1752.

46. Siriwardhana N., Lee, K.W., Kim, S.H., Ha, J.W., Jeon, Y.J., Food Sci. Technol. Int. 9 (2003) 339.

47. Yuan Y. V., Bone D. E., Carrington M. F., Food Chem.91 (2005) 485.

48. Bengueddour Y., El Hani S., El Ibaoui H., El Ayadi R., Brhadda N., Nat. Technol. 10 (2014) 29.

49. Devi G.K., Manivannan K., Thirumaran G., Rajathi F.A., Anantharaman P., Asian Pac. J. Trop. Med. 4 (2011) 205.

50. Toth G., Pavia H., Mar. Ecol. Prog. Ser. 192 (2000) 119.

51. Balboa E.M., Conde E., Moure A., Falque E., Dominguez H., Food Chem. 138 (2013) 1764.

(2017) ; http://www.jmaterenvironsci.com 